\title{
A Supramolecular Palladium Catalyst Displaying Substrate Selectivity by Remote Control
}

\author{
Paolo Zardi, Thierry Roisnel and Rafael Gramage-Doria*[a]
}

\begin{abstract}
Inspired by enzymes, such as cytochrome P-450, the study of the reactivity of metalloporphyrins continues to attract major interest in homogeneous catalysis. However, little is known to take benefit from the substrate recognition properties of porphyrins containing additional, catalytically-relevant active sites. Herein, we introduce such approach using supramolecular ligands derived from metalloporphyrins customized with rigid, palladium-coordinating nitrile groups. According to different spectroscopic studies (NMR, UV-vis, Xray diffraction, control experiments), the supramolecular ligands are able to accommodate pyridine derivatives as substrates inside the porphyrin pocket while the reactivity occurs in the peripheral side. By simply tuning a remote metal center, different binding events result in different catalyst reactivity: an enzyme-like feature leading to high levels of substrate selectivity when applied to representative palladium-catalyzed Suzuki-Miyaura reactions.
\end{abstract}

\section{Introduction}

In the search for more efficient and sustainable chemical transformations, homogeneous catalysis plays a prominent role..$^{1]}$ In this way, fine-tuning of transition metal catalysts by modification of the stereo-electronic properties of the ligand(s) attached to the metal center(s) is regarded as an essential process for further developments. ${ }^{[2]}$ As such, catalyst screening is largely dominated by traditional trial and error methods ${ }^{[3]}$ or through the selection of potential leads by high-throughput instrumentation. ${ }^{[4]}$ Recently, important efforts have been also devoted to rationally design powerful transition metal catalysts at will by computational methods in order to anticipate and predict a catalytic outcome. ${ }^{[5]}$ As an appealing alternative, the emergence of transition metal catalysis with supramolecular chemistry has led to a wide array of unique systems to tackle important issues that traditional approaches have difficulties to address. ${ }^{[6]}$ For example, catalyst encapsulation within covalent or supramolecular frameworks resulted in an increase of the catalyst stability and reactivity as well as a tool to control the chemo-, regio- and stereo-selectivity of a reaction outcome. ${ }^{[7]}$ Another approach is based on the use of non-covalent interactions such as ion-pair, hydrogen bonding or $\pi-\pi$ interactions between the catalyst and the substrate to dictate products selectivity. ${ }^{[8]}$ These non-covalent interactions are also being exploited to exponentially generate ligand libraries that are challenging to assemble by covalent bonds. ${ }^{\left[{ }^{[]}\right.}$Other strategies deal with transition metal-based catalysts that are able to switch between on/off states and those connected to sophisticated artificial molecular machineries. ${ }^{[10]}$

[a] Dr. P. Zardi, Dr. T. Roisnel, Dr. R. Gramage-Doria Univ Rennes, CNRS, ISCR-UMR 6226, F-35000 Rennes, France. E-mail: rafael.gramage-doria@univ-rennes1.fr

Supporting information and the ORCID identification number(s) for the author(s) of this article can be found under: $X X X$
Surprisingly, little catalytic systems have been proved successful in substrate selective catalysis, where the active catalyst is able to discriminate between similar substrates by modifying the substrate reactivity patterns. ${ }^{[11]}$ Such a concept, which is reminiscent of the high levels of substrate selection processes occurring in enzymes, is extremely difficult to mimic in non-natural transition metal catalysis ${ }^{[12]}$ and it is mainly associated to the high inner reactivity of transition metal complexes, which make difficult to discriminate between chemically similar substrates. ${ }^{[13]}$ Herein we report a strategy that is based on a set of supramolecular palladium catalysts that are stereo-electronically identical with a minimal variation in the nature of a cation located eight chemical bonds apart from the catalytically active sites. The nature of the metal center has a direct impact in the dynamic lability of the substrate-catalyst interaction, thus making possible to control the reactivity and substrate selectivity patterns of the catalyst in representative Suzuki-Miyaura reactions.

We reasoned that metalloporphyrins appended with rigid, coordinating nitrile groups could be suited for this purpose since (1) different metal centers (A, Figure 1) can easily be embedded in the porphyrin core affecting the strength of the apical binding of pyridine-containing substrates, ${ }^{[14]}$ (2) the stability of mesosubstituted metalloporphyrins in transition metal catalysis is well known, ${ }^{[15]}$ and (3) catalytically active metal centers, such as palladium are known to coordinate to nitrile groups (Figure 1). ${ }^{[16]}$ Previously, Sanders reported porphyrin nano-rings acting as substrate-preorganization reactors for purely organic transformations (Diels Alder) and their impact in reaction rate and product selectivity. ${ }^{[17]}$ Later, Nishibayashi and Uemura reported zinc-porphyrins decorated with phosphine rhodium and iridium fragments as catalysts for hydrosilylation reactions, although the substrate-recognition properties of the zinc-porphyrin core were not exploited. ${ }^{[18]}$

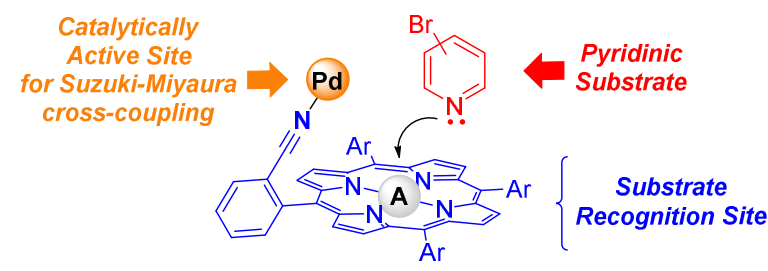

Figure 1. Supramolecular palladium catalyst design. $\mathrm{Ar}=2-\mathrm{CN}-\mathrm{C}_{6} \mathrm{H}_{4}$.

\section{Results and Discussion}

Synthesis of the supramolecular ligands. Starting from 2cyanobenzaldehyde and pyrrole, porphyrin L1 was synthesized as a suitable framework to build up our supramolecular catalysts (Scheme 1). Appropriate metal insertion reactions following wellestablished protocols led to the synthesis of ligands L2-L4 that 
contain different metal centers ( $\mathrm{Zn}, \mathrm{Ru}$ and $\mathrm{Cu}$ ) sitting inside the porphyrin core (Scheme 1). They were fully characterized by NMR and HRMS analysis (see details in the Experimental Section and the Supporting Information). In addition, these studies revealed that the ligands L1-L4 exist, as it could be anticipated, ${ }^{[14]}$ as a mixture of four possible atropoisomers ( $\alpha \alpha \alpha \alpha, \alpha \beta \alpha \beta, \alpha \alpha \beta \beta, \alpha \alpha \alpha \beta)$ due to the steric restrictions imposed by the ortho substitution pattern of the meso aryl groups that prevent free rotation around these groups and the porphyrin core. Although the atropoisomers are conformationnally stable at room temperature, they easily interconvert each other by standing in solution at high temperatures, ${ }^{[19]}$ making them compatible to be used in transition metal catalysis where usually high temperatures are required. L2 was further characterized by a single-crystal Xray diffraction study that clearly showed that the nitrile groups are located above and below the porphyrin plane leaving the zinc center available for binding to pyridine derivatives (Scheme 1). ${ }^{[20]}$ For comparison purposes (vide infra), L5 -with no nitrile groupsand L6 -with one nitrile group- were also synthesized and characterized (Scheme1, see details in the Experimental Section and the Supporting Information).

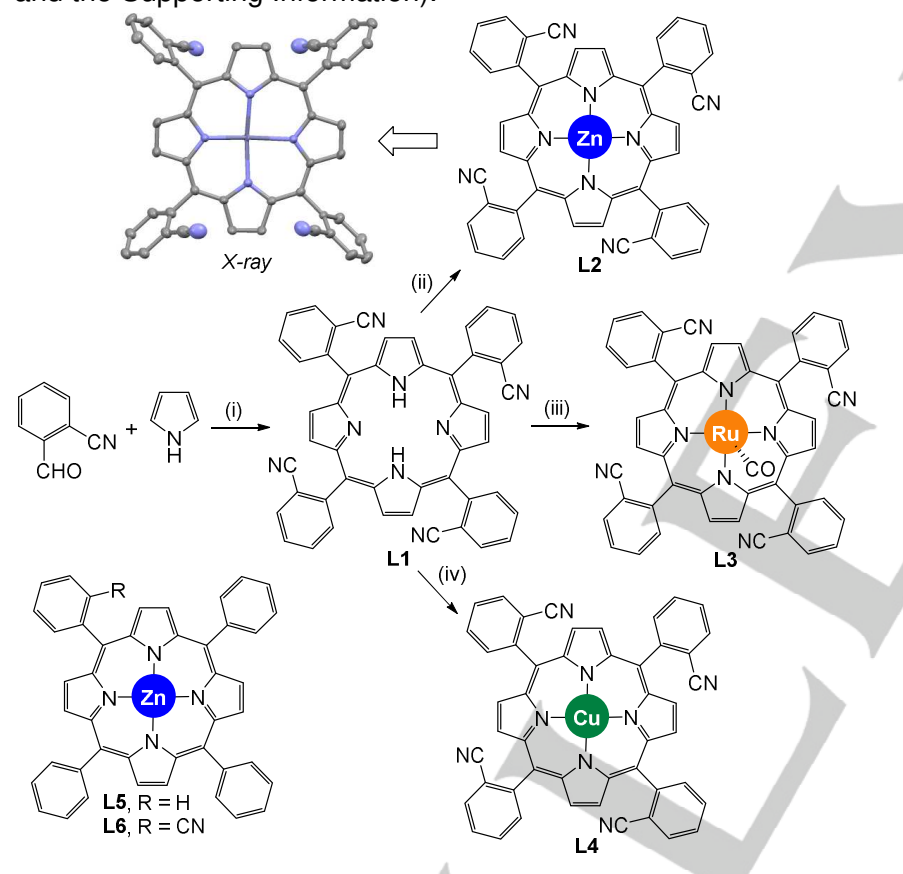

Scheme 1. Synthesis of the supramolecular ligands L1-L6 used in this study. Reaction conditions: (i) Propionic acid, reflux, $2 \mathrm{~h}$; (ii) $\mathrm{Zn}(\mathrm{OAc})_{2} \cdot 2 \mathrm{H}_{2} \mathrm{O}$, $\mathrm{CHCl}_{3}: \mathrm{MeOH}$, reflux, $2 \mathrm{~h}$; (iii) $\mathrm{Ru}_{3}(\mathrm{CO})_{12}, 1,3$-dichlorobenzene, reflux, $1.5 \mathrm{~h}$; (iv) $\mathrm{Cu}(\mathrm{OAc})_{2} \cdot 2 \mathrm{H}_{2} \mathrm{O}, \mathrm{CHCl}_{3}: \mathrm{MeOH}$, reflux, $5 \mathrm{~h}$.

Binding studies of the supramolecular ligands towards different pyridine substrates. Next, we studied the supramolecular capabilities of L2-L6 to bind via the embedded metal centre $(\mathrm{Zn}, \mathrm{Ru}, \mathrm{Cu})$ to different pyridine-containing substrates that could be used in Pd-catalysed carbon-carbon bond-forming reactions such as 2-bromopyridine (P2), 3bromopyridine (P3) and 4-bromopyridine (P4). ${ }^{1} \mathrm{H}$ NMR and UVvis titration studies were performed combining L2-L6 with P2-P4, respectively, and their association constants $\left(K_{1.1}\right)$ are reported in Table 1 (see details in Figures S11-S21 in the Supporting Information). The different binding behaviour associated to the bulkiness of the substrates P2-P4 and the nature of the metal embedded in L2-L4 was evidenced. For instance, P2 did not bind to any metalloporphyrin ligand due to important steric effects imposed by the ortho-substitution pattern. ${ }^{[15 c, 21]}$ On the other hand, P3 and P4 did reversibly bind to both $\mathrm{Zn}$-containing $\mathbf{L} 2$ and $\mathrm{Ru}-$ containing L3 in a 1:1 stoichiometry with comparable

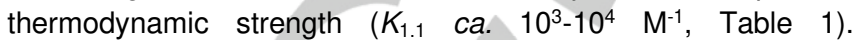
Importantly, ${ }^{1} \mathrm{H}$ NMR analysis indicated that the interactions between Ru-containing L3 with P3 and P4, respectively, are kinetically less labile (thus more coordinative) as compared to the interactions involving the $\mathrm{Zn}$-containing $\mathbf{L} 2$ upon binding to $\mathbf{P} \mathbf{3}$ and $\mathbf{P 4}$, respectively. Thereby, when a solution of $\mathbf{L} 3$ was titrated with P3 and followed by ${ }^{1} \mathrm{H}$ NMR spectroscopy, a slow ligand exchange was witnessed at the NMR timescale leading to the presence of free 3-bromopyridine (P3) and the pyridinecoordinated assembly [L3.P3] without formal changes in the chemical shifts for each set of proton signals. Conversely, the same experiment being performed with Zn-containing L2 showed only one set of signals even in the presence of an excess of P3, thus proving the fast exchange behaviour for the assembly [L2.P3] between bounded and unbounded bromopyridine. ${ }^{[22]} \mathrm{Cu}-$ porphyrin ligand L4 displayed negligible binding to all bromopyridines P2-P4. ${ }^{[23]}$ Overall, the general trend for the binding strength of the bromopyridine $\cdots$ metalloporphyrin interaction could be summarized as $\mathrm{Cu}>\mathrm{Zn}>\mathrm{Ru}$.

Table 1. Binding constants $K_{1.1}\left(\mathrm{M}^{-1}\right)$ of the assemblies between ligands L2-L6 and different pyridine derivatives. ${ }^{[a]}$

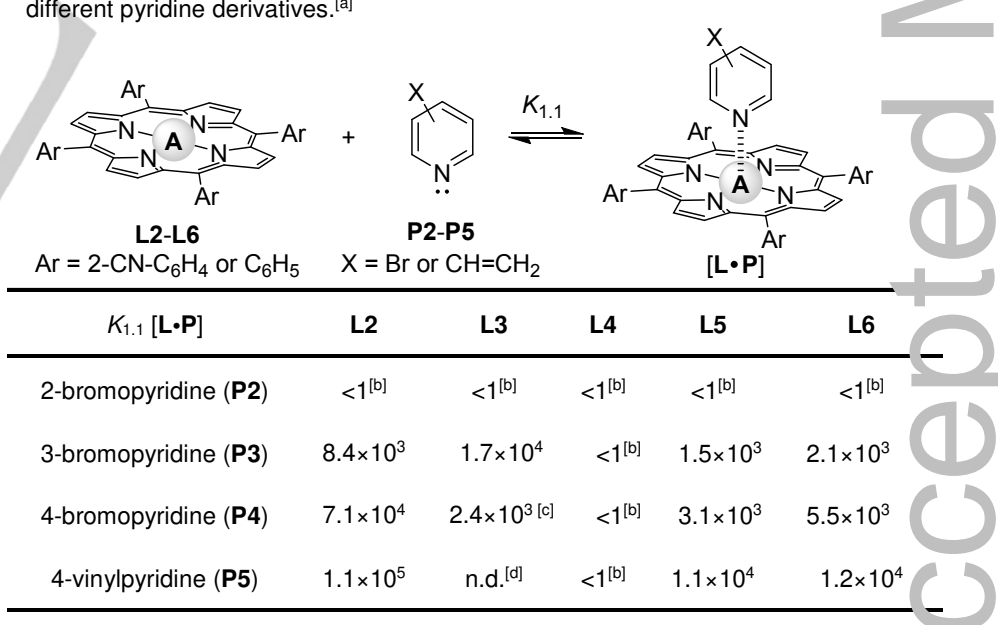

[a] Determined by UV/Vis titrations $\left(\mathrm{CH}_{2} \mathrm{Cl}_{2}\right.$ as solvent) and ${ }^{1} \mathrm{H} \mathrm{NMR}\left(\mathrm{CDCl}_{3}\right.$ as solvent) analysis, errors estimated to be $<5 \%$. [b] Negligible binding. [c] The bin .ig constant value may be underestimated likely due to partial decomposition of $\mathbf{P}_{\mathbf{4}}$ during the titration; ${ }^{1} \mathrm{H}$ NMR competition experiments showed that the association constants for L2 and L3 with P4 are in the same order of magnitude (see details in Figure S25 in the Supporting Information). [d] n.d. = Not determined.

For comparison purposes, the binding of L5 and $\mathbf{L} 6$ to the different bromopyridines P2-P4 was also studied (Table 1). As for the other porphyrin ligands, no binding was observed for P2 with 
L5 and L6, respectively. Interestingly, the binding of bromopyridine $\mathbf{P} \mathbf{3}$ with $\mathbf{L} \mathbf{5}$ and $\mathbf{L 6}$, respectively, was 4-fold weaker than with its structurally related ligand $\mathbf{L 2}$; and the binding of the bromopyridine P4 with L5 and L6, respectively, was 13-fold weaker than with its structurally related ligand $\mathbf{L} 2$. These findings indicate that increasing the number of electron withdrawing nitrile groups around the zinc centre increases the binding strength towards the same type of substrate. This was exemplified in the solid state as we managed to obtain single-crystals suitable for $X$ ray diffraction studies for the assembly of L2 and L5 with 4vinylpyridine (P5), respectively (Figure 2). The $\mathrm{Zn} \cdots \mathrm{N}$ distance between the pyridine derivative and the $\mathrm{Zn}$ centre in [L2・P5] was much shorter $\left(d_{Z n \ldots N}=2.139 \AA\right)$ than in [L5•P5] $\left(d_{Z n \ldots N}=2.183 \AA\right)$, indicating that the supramolecular ligand L2 binds to pyridine derivatives stronger than unfunctionalized $\mathbf{L} \mathbf{5}$. This was inferred in solution as well, since P5 binds 10 -fold stronger to $\mathbf{L} 2$ than to L5 $\left(K_{1.1}=1.1 \times 10^{5}\right.$ vs $K_{1.1}=1.1 \times 10^{4}$, Table 1$)$. It can be concluded that the strong electron withdrawing ability of nitrile groups within the porphyrin ring of $\mathbf{L} 2$ decreases the electron density of the $\mathbf{Z n}$ centre and consequently, increases its binding strength to the pyridine nitrogen as compared to $\mathbf{L} \mathbf{5}$. In addition, we noticed that the increase of the binding strength of L2 to P3-P5 is likely a consequence of the increase of the electron-donating properties of the substituents in the pyridine ring from P3 to P5 (Table 1). The same trend was observed for the binding of L5 and L6 to P3$\mathbf{P 5}$, respectively (Table 1).
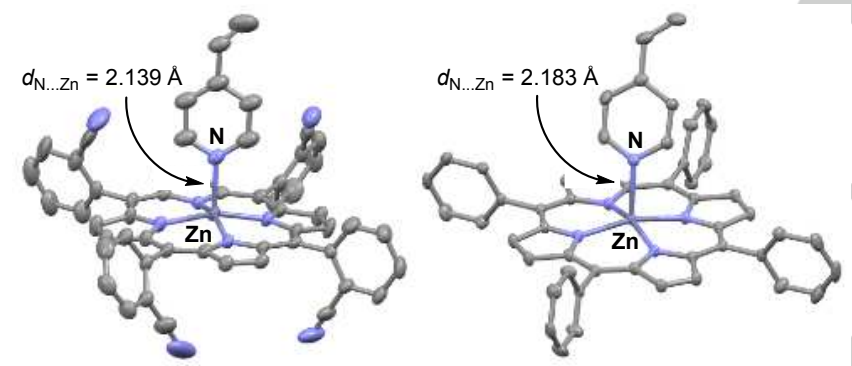

Figure 2. ORTEP drawing of the assemblies [L2·P5] (left) and [L5•P5] (right) determined by single crystal $\mathrm{X}$-ray diffraction studies with thermal ellipsoids at $50 \%$ probability. All hydrogen atoms are omitted for clarity.

Pd-catalyzed cross-coupling studies. Having established that the structurally-equivalent supramolecular ligands L2-L4 were able to bind in a different manner to bromopyridines P2-P4 by exclusive tuning of the binding capabilities of the embedded metal center $(\mathrm{Zn}, \mathrm{Cu}, \mathrm{Ru})$, we investigated these ligands in representative Pd-catalysed Suzuki-Miyaura reactions. Toluene was used as solvent since its relative low polarity favors the interaction between pyridine derivatives and metalloporphyrins to occur. ${ }^{[15 c]}$ We also hypothesized that the low coordinating properties of toluene will enhance the binding of nitrile groups to catalytically active palladium ions. 3-Bromopyridine (P3) was thus treated with phenylboronic acid in the presence of catalytic amounts of $\left[\mathrm{Pd}(\mathrm{OAc})_{2}\right]$, which is known to be a good pre-catalyst for carbon-carbon bond-forming reactions, and ligands L2-L4, respectively (Figure 3). As it is the case in many cross-coupling reactions, ${ }^{[2,3]}$ the catalytic system was formed in situ using a tenfold excess of ligand per palladium ( $5 \mathrm{~mol} \%$ of $\mathbf{L}$ vs $0.5 \mathrm{~mol} \%$ of
$\left.\left[\mathrm{Pd}(\mathrm{OAc})_{2}\right]\right)$. This ensures that most of the palladium remains coordinated to the nitrile groups of the ligands (see Figure S11 in the Supporting Information for reaction optimization). ${ }^{[16]}$

The conversion of $\mathbf{P} \mathbf{3}$ for each one of the three reactions was followed in time by GC and the corresponding kinetic profiles are displayed in Figure $3 a$. The reactions in the presence of the supramolecular ligands L2-L4 each gave a substantially different kinetic profile as a consequence of the differences related to their binding properties towards P3. The dynamic but strong enough binding of P3 to the zinc center of L2 ensured the best catalytic performance with almost full conversion after 40 minutes; while the reaction with a ligand that is unable to interact with the substrate P3, such as the copper-porphyrin L4, was slow with $90 \%$ conversion reached after 180 minutes. On the other hand, the strong kinetic stability of the assembly [L3.P3] caused an important catalyst deactivation when using L3 as ligand, with a conversion of $\mathbf{P} \mathbf{3}$ of $35 \%$ after 3 hours. To determine the cooperativity of $\mathrm{Zn} \cdots \mathrm{N}$ and $\mathrm{Pd} \cdots \mathrm{N} \equiv \mathrm{C}$ interactions suggested in the catalytic experiments for the best supramolecular ligand (L2), we performed a set of control experiments with ligands lacking nitrile groups (L5 at 5 mol\%), with one nitrile group (L6 at 5 mol\%) and with mixtures of the individual components of L2 ( $\mathbf{5} 5$ at $5 \mathrm{~mol} \%$ and benzonitrile at $20 \mathrm{~mol} \%$, that is a 1:4 ratio). The reaction was also conducted without any ligand. All control experiments provided significantly lower reaction rates as compared to the supramolecular ligand L2 (Figure $3 b$ ). This highlights the positive effect of (1) the substrate recognition of P3 inside the Znporphyrin of $\mathbf{L} 2$ and (2) the increase of the palladium reactivity due to the presence of four nitrile groups in the periphery, thereby increasing the effective concentration of palladium at close proximity of the substrate. ${ }^{[24]}$
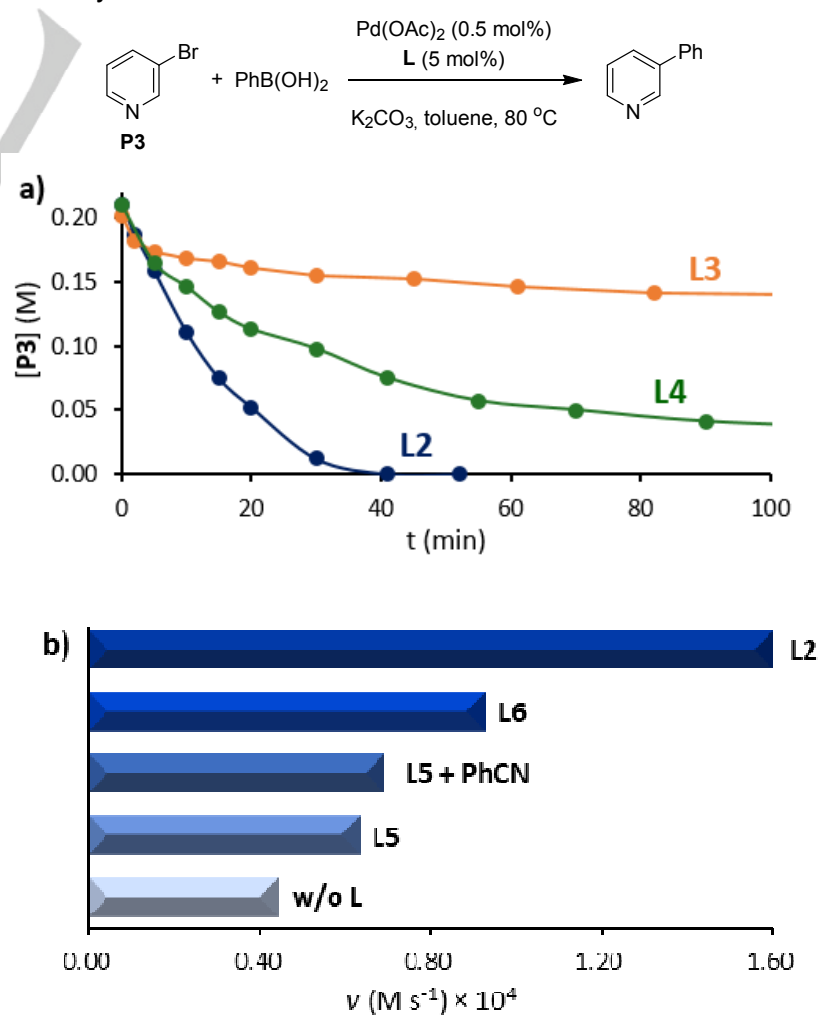
Figure 3. (a) Conversion of P3 vs time using L2-L4, respectively. (b) Reaction rates measured in the range of $20-40 \%$ conversion for control experiments. Homocoupling was found to be $<5 \%$, thus conversion of P3 virtually corresponds to the yield of product

In view of the unique features of our supramolecular design and the importance of developing artificial enzyme-like catalysts with substrate selectivity features, ${ }^{[6-13]}$ we studied the behavior of the supramolecular catalyst L2-Pd with the other bromopyridine regioisomers: 2-bromopyridine (P2) and 4-bromopyridine (P4). The conversion of each regioisomer P2-P4 was followed in time by $\mathrm{GC}$ in the presence and absence of L2 (Figure 4). The reactivity of $\mathbf{P} \mathbf{2}$ remained almost unaffected by the presence or absence of $\mathbf{L} 2$ due to the inability of the ortho regioisomer $\mathbf{P} \mathbf{2}$ to bind to the Zn center of $\mathbf{L 2}{ }^{\left[{ }^{25]}\right.} \mathbf{P 4}$, which is known to be the most reactive regioisomer of the series, displays a kinetic profile completely unaffected by the absence or presence of the supramolecular ligand L2 with full conversion after 50 minutes in both cases. Interestingly, when comparing the reactivity of P3 in the presence or absence of the supramolecular ligand L2, it was found that the supramolecular ligand L2 tuned the reactivity of P3 making this substrate as reactive as the most reactive regioisomer of the series, namely $\mathbf{P 4}$, with full conversion at $\mathbf{5 0}$ minutes as well (Figure 4).
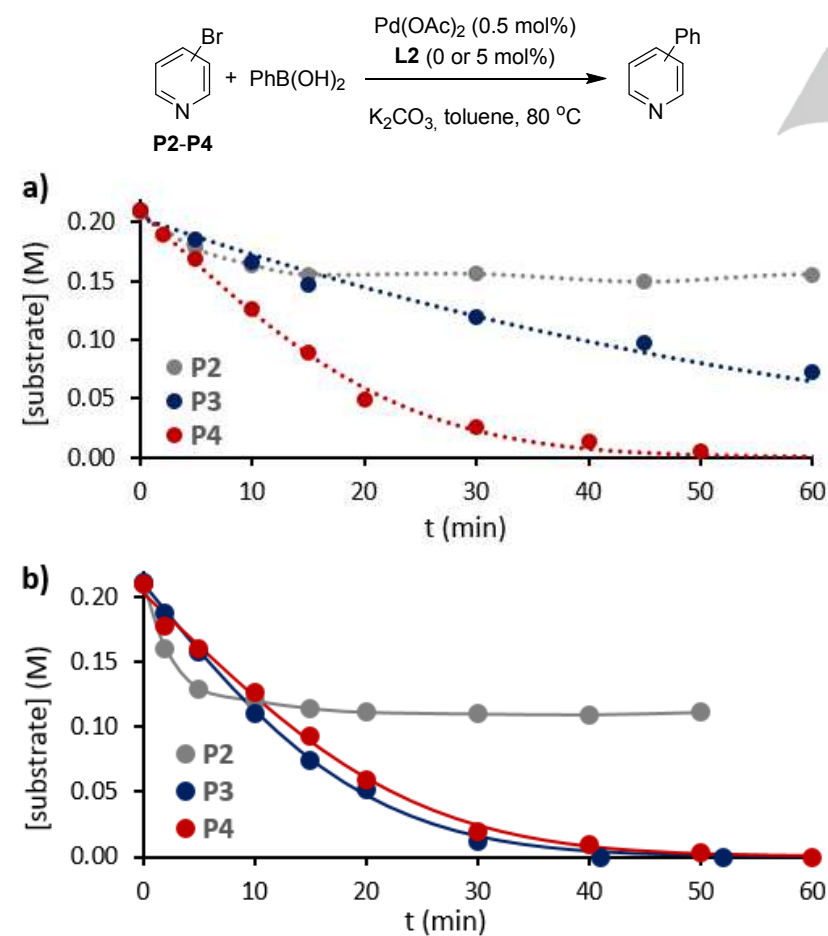

Figure 4. (a) Conversion of P2-P4 vs time in the absence of L2. (b) Conversion of P2-P4 vs time in the presence of L2. Homocoupling was found to be $<5 \%$, thus conversion of P2-P4 virtually corresponds to the yield of product.

The substrate selectivity displayed by the supramolecular ligand L2 was further assessed by performing competition experiments with 3-bromopyridine (P3) and bromobenzene (B1) (Figure 5 ). In the presence of both substrates, bromobenzene (B1) followed a similar kinetic trend regardless of the presence of
L2. On the other hand, 3-bromopyridine $(\mathbf{P} 3)$ reacted in a more efficient manner (twofold increase in conversion) when using supramolecular ligand L2 even in the presence of the competing substrate B1 (Figure 5). Thereby, L2-Pd was able to promote palladium catalysis preferentially with the substrate that is remotely recognized by the supramolecular catalyst even in the presence of any additional aryl bromides such as B1. It is important to note that the supramolecular ligands L2-L4 could be recovered at the end of the reactions via acid/base workup, observing no $\mathrm{Zn} / \mathrm{Pd}$ transmetallation, which indicates the robustness of this approach (see details in the Supporting Information).

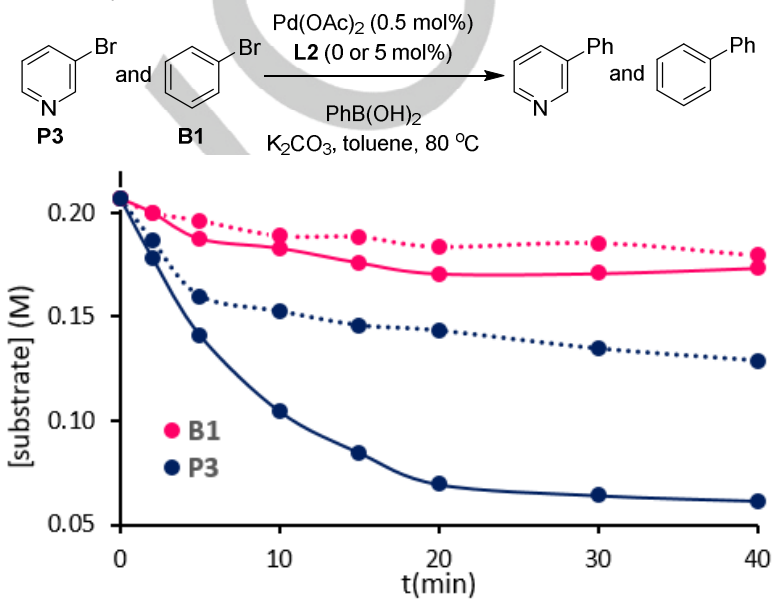

Figure 5. Conversion of $\mathbf{P} \mathbf{3}$ and $\mathbf{B} \mathbf{1}$ vs time in the absence (dashed lines) and presence (continuous lines) of L2 under competitive conditions. Homocoupling was found to be $<5 \%$, thus conversion of substrates virtually corresponds to yield of product.

Assessment of the substrate selectivity observed for supramolecular ligand L2. First, the ability of the supramolecular ligand L2 to bind to palladium ions was determined by HRMS analysis by mixing $\mathbf{L} 2$ with the catalyticallyrelevant $\left[\mathrm{Pd}(\mathrm{OAc})_{2}\right]$ complex in a 1:4 ratio. The mass spectrum showed a peak at $\mathrm{m} / z 884.046 \pm 2 \mathrm{ppm}$ having exactly the isotopic profile corresponding to $[\mathrm{L} 2+\mathrm{Pd}]^{+}$(see Figures S31-S32 in the Supporting Information). The same type of analysis performed with L5, which lacks nitrile groups, revealed no binding of palladium, which agrees well with $\mathrm{Pd} \cdots \mathrm{N} \equiv \mathrm{C}$ binding in the case of [L2+Pd]. The ${ }^{1} \mathrm{H}$ NMR spectra obtained after titration of $\mathbf{L} 2$ with $\mathrm{Pd}(\mathrm{OAc})_{2}$ in $\mathrm{CDCl}_{3}$ at room temperature revealed small downfield shifts at $\delta$ ca. 8.25-8.50 ppm (see Figure S28-S29 in the Supporting Information) for the signals associated to the protons $\mathrm{H}_{\mathrm{o}}$ located in ortho position with respect to the nitrile groups (Scheme 2) within L2. Similar observations have been reported for related systems. ${ }^{[161]}$ Furthermore, the interaction of nitrile groups with palladium ions has been experimentally evidenced by ${ }^{1} \mathrm{H}$ NMR and HRMS; and supported by DFT calculations elsewhere. ${ }^{[16 \mathrm{~d}, \mathrm{e}, \mathrm{n}, \mathrm{o}]}$ Other analysis such as UV-vis, IR and ${ }^{13} \mathrm{C}$ NMR were unfortunately not conclusive due to the very small spectroscopic changes associated to the $\mathrm{Pd} \cdot \cdots \mathrm{N} \equiv \mathrm{C}$ interaction. ${ }^{[26]}$ On the other hand, the proton signals belonging to palladiumcoordinated acetate ligands were observed as a major singlet at 
$\delta=2.03$ ppm during the titration of $\left[\mathrm{Pd}(\mathrm{OAc})_{2}\right]$ with $\mathbf{L 2}$ (see Figure S28 in the Supporting Information). By increasing the amounts of palladium, there were very minor proton signals that begin to appear at $\delta$ ca. $1.90-2.05 \mathrm{ppm}$ (see Figure S30 in the Supporting Information), which could involve the presence of acetate ligands bridging two palladium ions according to literature precedents. ${ }^{[27]}$ Nevertheless, these data shows that palladium ions are able to simultaneously bind to the nitrile groups of $\mathbf{L 2}$ and the acetate ligands as well. The fact that structurally related square planar $\left[\mathrm{Pd}(\mathrm{RCN})_{2}\left(\mathrm{RCO}_{2}\right)_{2}\right](\mathrm{R}=$ alkyl, aryl) species are known in the literature, ${ }^{[28]}$ enabled us to propose a plausible structure of the pre-catalyst $\mathbf{A}$ (Scheme 2) were two coordinating sites of the palladium center are occupied with a nitrile group from the supramolecular ligand L2 and an acetate ligand, respectively, and the other two vacant sites might involve coordination of a nitrile group (either from the same ligand -chelate- or another molecule of ligand -dimer-) and acetate ligands as terminal or bridging ligands.

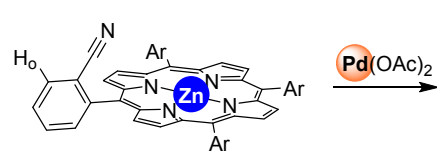

L2

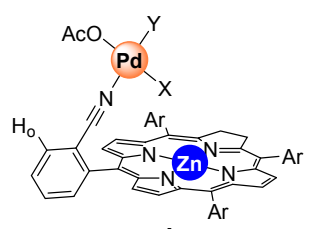

$\mathrm{X}=\mu-\mathrm{OAc}$ or $\mu_{2}-\mathrm{OAc}$

$\mathrm{Y}=\mathrm{N} \equiv \mathrm{R}$ from same or different $\mathbf{L} \mathbf{2}$

Scheme 2. Formation of a plausible pre-catalyst $\mathbf{A}$ upon treatment of $\mathbf{L} 2$ with $\left[\mathrm{Pd}(\mathrm{OAc})_{2}\right] . \mathrm{Ar}=2-\mathrm{CN}-\mathrm{C}_{6} \mathrm{H}_{4}$.

To verify that the palladium '-nitrile binding was compatible with the zinc'*pyridine binding, ${ }^{1} \mathrm{H}$ NMR spectroscopy studies were performed by increasing amounts of palladium ions to a solution of the ligand-substrate assembly [L2·P3] (Figure 6). For instance, the addition of 0.2 equivalents of $\left[\mathrm{Pd}(\mathrm{OAc})_{2}\right]$, which is already beyond the ratio used in the catalytic experiments (Pd:L2 $=1: 10$ ), clearly indicates the persistence of the binding of bromopyridine P3 to the zinc center of $\mathbf{L 2}$ as no downfield shifts were observed for the signals belonging to the pyridinic protons (Figure 6). Further increase of the amounts of $\left[\mathrm{Pd}(\mathrm{OAc})_{2}\right]$ to the solution of the ligand-substrate assembly [L2·P3] showed little changes associated to the porphyrin signals and persistence of the zinc-coordinated pyridinic signals albeit with a concomitant decrease of their intensity (Figure 6). The stability of the zinc $\cdots$ pyridine binding with the palladium $\cdots$ nitrile binding was further exemplified upon titration of $\mathbf{P} \mathbf{3}$ to an equimolar solution of L2 and $\left[\mathrm{Pd}(\mathrm{OAc})_{2}\right]$, that is the opposite study as the one depicted in Figure 6 . The binding constant measured by UV-vis studies for the ligand-substrate assembly [L2·P3] was found to be $K_{1.1}=$ $8.2 \times 10^{3} \mathrm{M}^{-1}$ (see Figure S23 in the Supporting Information), a value which is almost the same -within the error of the measurement- as the one observed without the presence of palladium $\left(K_{1.1}=8.4 \times 10^{3} \mathrm{M}^{-1}\right.$, Table 1$)$.

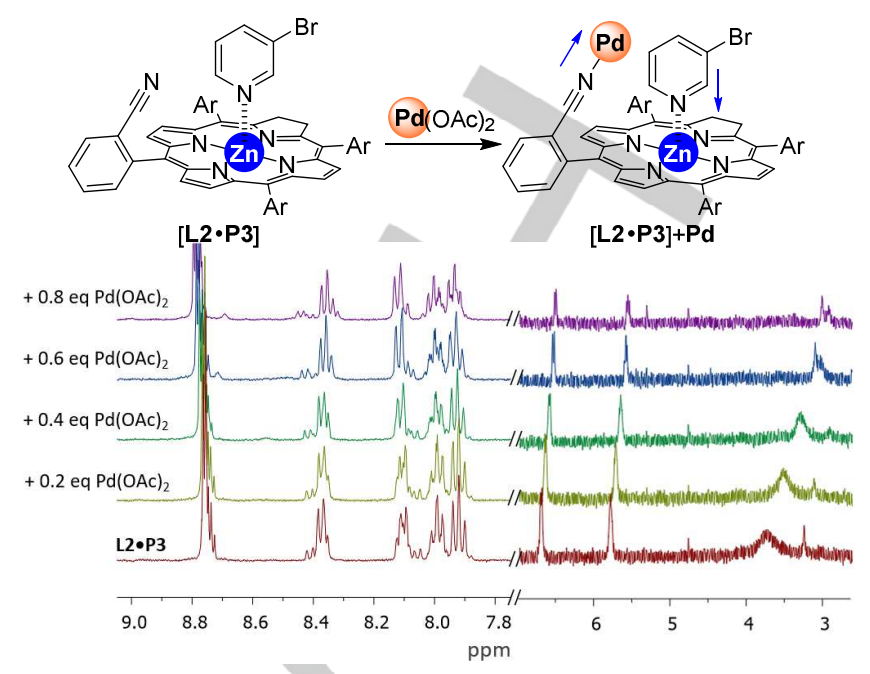

Figure 6. Reaction of self-assembly [L2·P3] with $\left[\mathrm{Pd}(\mathrm{OAc})_{2}\right]$ (top) and the corresponding ${ }^{1} \mathrm{H}$ NMR titration (bottom). The signals related to the porphyrin ligand (left) and the coordinated pyridine signals (right) are shown. A spectrum was registered for the initial [L2·P3] adduct (red line) and for each one of the additions of $\left[\mathrm{Pd}(\mathrm{OAc})_{2}\right]$ (from 0.2 equivalents to 0.8 equivalents). $\mathrm{Ar}=2-\mathrm{CN}$ $\mathrm{C}_{6} \mathrm{H}_{4}$. Blue arrows indicate the binding strength on each component (top).

According to preliminary molecular modelling (PM3minimized calculations, see details in the Supporting Information) the oxidative addition of $\mathbf{P} \mathbf{3}$ to the palladium center and the further reductive elimination steps are doable with the presence of $\mathrm{Zn}$ ”pyridine interactions (Figure 7). These calculations were done with one palladium ion binding to a single nitrile group of the ligand, which is comparable to the case in catalysis, where the ligand is in excess with respect to palladium. This indicates that the high substrate selectivity observed in the catalytic experiments by L2 for P3 compared to the other regioisomers P2 and P4 (Figure 4) and the competing substrate B1 (Figure 5) is due to the ideal substrate preorganization fit of the supramolecular ligand L2 via a putative 12-membered palladacycle intermediate (Figure 7). Such supramolecular ligands, with this unique action mode, might be regarded as an alternative to the sensitive phosphine ligands for cross-coupling reactions involving heterocyclic motifs. ${ }^{[2]}$

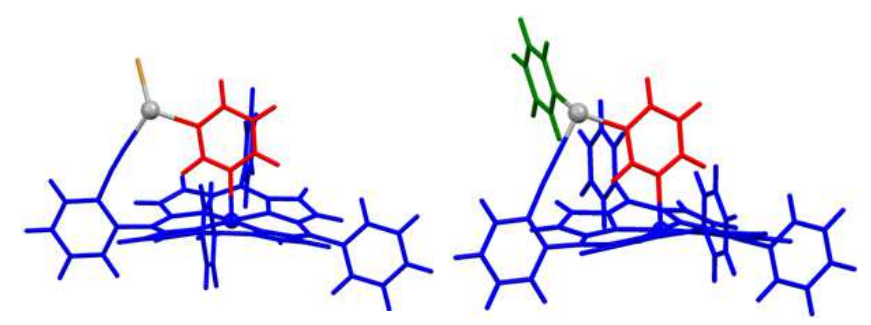

Figure 7. PM3-minimized molecular modelling for the plausible transition state of the oxidative addition of P3 (left) and the plausible transition state prior to the reductive elimination step (right). Color code: supramolecular ligand with one nitrile group (blue), pyridine scaffold (red), palladium (gray) bromine atom (gold) and phenyl ring (green). 


\section{Conclusions}

In conclusion, we have introduced an approach to design supramolecular ligands to target substrate selective reactions in palladium catalysis. This was possible by merging the substrate recognition properties of metalloporphyrins and the incorporation of metal coordinating functionalities such as nitriles in a precise, peripheral position to bind catalytically active palladium ions at close proximity to the substrate. This strategy enabled to find a suitable supramolecular palladium catalyst in which the substrate recognition site is eight chemical bonds apart from the catalytically active site. By screening a few cations $(\mathrm{Cu}, \mathrm{Zn}, \mathrm{Ru})$ in the substrate recognition site, the supramolecular ligand L2, which contains zinc, was identified as the most promising one to tune the reactivity of one regioisomer to make it as reactive as the most reactive one even in the presence of competing substrates; features that are reminiscent of enzymes. ${ }^{[12]}$ Due to the ease of modification of metalloporphyrin scaffolds and the multiple possibilities in terms of peripheral design they offer, one could anticipate that new reactions could be disclosed applying such principles.

\section{Experimental Section}

General: Toluene and dichloromethane were purified by a MB SPS-800 purification system. Pyrrole and 1,3-dichlorobenzene were dried over $\mathrm{CaH}_{2}$ and distilled prior to use. $\mathrm{CDCl}_{3}$ was filtered over alumina and stored under argon over molecular sieves. The free-base prorphyrin for L6 was synthesised by following a reported procedure. ${ }^{[30]}$ All the other employed chemicals were purchased from commercial sources and used as received. Unless otherwise specified, reactions were carried out under argon atmosphere employing standard Schlenk techniques and vacuum line manipulations. ${ }^{1} \mathrm{H}$ NMR and ${ }^{13} \mathrm{C}$ NMR spectra were recorded on Bruker GPX (400 MHz) spectrometer. ${ }^{1} \mathrm{H}$ NMR spectra were referenced to residual protiated solvent $\left(\delta=7.26 \mathrm{ppm}\right.$ for $\mathrm{CDCl}_{3}$ and $2.05 \mathrm{ppm}$ for acetone- $\left.d_{6}\right) .{ }^{13} \mathrm{C}$ NMR spectra were referenced to $\mathrm{CDCl}_{3}(\delta=77.16 \mathrm{ppm})$. The catalytic reactions were monitored using a Shimadzu 2014 gas chromatograph equipped with EquityTM-1 Fused Silica capillary column (30 $\mathrm{m} \times 0.25 \mathrm{~mm} \times 0.25 \mu \mathrm{m})$ and a FID detector; conversion and selectivity were determined using dodecane as internal standard. Molecular modelling calculations were performed using PM3-Spartan molecular modelling program. UV-Vis absorption spectra were recorded using a Specord 205 UV-vis-NIR spectrophotometer and quartz cuvettes of $1 \mathrm{~cm}$ pathlength. Mass spectroscopy and microanalysis were performed in the laboratories of the Centre Régional de Mesures Physiques de l'Ouest (CRMPO, Universitè de Rennes 1, Rennes, France).

\section{Synthesis of the porphyrin compounds}

Synthesis of L1: Under light cover, 2-cyanobenzaldehyde (1.89 g, 14 $\mathrm{mmol})$ was dissolved in propionic acid $(100 \mathrm{~mL})$ and heated to reflux, pyrrole $(1.0 \mathrm{~mL}, 14 \mathrm{mmol})$ was added dropwise and the so-obtained dark mixture was furtherly refluxed for 2 hours. The solvent was removed by vacuum distillation and the crude was purified by chromatography $\left(\mathrm{SiO}_{2}\right.$, $\mathrm{CH}_{2} \mathrm{Cl}_{2}$ as eluent). The fraction containing the porphyrin was evaporated to dryness and crystallized from a $\mathrm{CH}_{2} \mathrm{Cl}_{2} / \mathrm{Heptane}$ mixture to give $\mathbf{L} 1$ as a dark violet solid (121 mg, 4.7\%). Analytical data matched those found in the literature. ${ }^{[31]}{ }^{1} \mathrm{H}$ NMR $\left(400 \mathrm{MHz}, \mathrm{CDCl}_{3}\right) \delta 8.75-8.67(8 \mathrm{H}, \mathrm{m}), 8.43-$ $8.18(4 \mathrm{H}, \mathrm{m}), 8.17-8.07(4 \mathrm{H}, \mathrm{m}), 8.03-7.89(8 \mathrm{H}, \mathrm{m})$.
General procedure for zinc porphyrins: In air atmosphere, the opportune free-base porphyrin $(0.16 \mathrm{mmol})$ and $\mathrm{Zn}(\mathrm{AcO})_{2} \cdot 2 \mathrm{H}_{2} \mathrm{O}(140 \mathrm{mg}$, $0.64 \mathrm{mmol}$ ) were dissolved in $25 \mathrm{~mL}$ of a $\mathrm{CHCl}_{3} / \mathrm{MeOH} 4: 1$ mixture. The mixture was refluxed for two hours, when no free-base porphyrin was detected by TLC analysis, and evaporated to dryness. The reaction crude was filtered over a short pad of alumina using $\mathrm{CH}_{2} \mathrm{Cl}_{2}$ as eluent. The fraction containing the porphyrin complex was evaporated to dryness.

L2: Quantitative yield. Analytical data matched those found in the literature. ${ }^{[19 a]}{ }^{1} \mathrm{H}$ NMR $\left(400 \mathrm{MHz}, \mathrm{CDCl}_{3}\right) \delta 8.80-8.74(\mathrm{~m}, 8 \mathrm{H}), 8.47-8.22$ (m, 4H), $8.15-8.04(\mathrm{~m}, 4 \mathrm{H}), 8.04-7.86(\mathrm{~m}, 8 \mathrm{H})$. HRMS (ESI) $\mathrm{m} / \mathrm{z}$ : [M] ${ }^{+}$ calcd. for $\mathrm{C}_{48} \mathrm{H}_{24} \mathrm{~N}_{8}{ }^{64} \mathrm{Zn} 776.14099$, found 776.1401. UV-vis $\left(\mathrm{CH}_{2} \mathrm{Cl}_{2}\right): \lambda_{\max }$ $(\log \varepsilon) 421$ (5.73), 549 (4.34).

L6: Quantitative yield. ${ }^{1} \mathrm{H}$ NMR $\left(400 \mathrm{MHz}, \mathrm{CDCl}_{3}\right) \delta 8.98(1 \mathrm{H}, \mathrm{d}, J=4.7$ $\mathrm{Hz}$ ), $8.97-8.93(6 \mathrm{H}, \mathrm{m}), 8.73(1 \mathrm{H}, \mathrm{d}, J=4.7 \mathrm{~Hz}), 8.35(1 \mathrm{H}, \mathrm{d}, J=6.9 \mathrm{~Hz})$, $8.23(6 \mathrm{H}, \mathrm{m}), 8.09(1 \mathrm{H}, \mathrm{dd}, J=7.7, J=1.2 \mathrm{~Hz}),, 7.98(1 \mathrm{H}, \mathrm{td}, J=7.6, J=$ $1.5 \mathrm{~Hz},), 7.90(1 \mathrm{H}, \mathrm{td}, J=7.7, J=1.2 \mathrm{~Hz}),, 7.77(9 \mathrm{H} \mathrm{m},) .{ }^{13} \mathrm{C}$ NMR $\delta 150.8$ (C), 150.5 (C), 150.4 (C), 149.7 (C), 146.8 (s), 142.8 (C), 142.8 (C), 135.0 (s), $134.7(\mathrm{CH}), 134.7(\mathrm{CH}), 134.6(\mathrm{CH}), 134.5(\mathrm{CHJ}), 133.1(\mathrm{CH}), 132.5$ $(\mathrm{CH}), 132.3(\mathrm{CH}), 131.7(\mathrm{CH}), 130.8(\mathrm{CH}), 128.6(\mathrm{CH}), 127.7(\mathrm{CH}), 126.8$ $(\mathrm{CH}), 126.7(\mathrm{CH}), 126.7(\mathrm{CH}), 126.7(\mathrm{CH}), 126.7(\mathrm{CH}), 122.3(\mathrm{C}), 121.7$ (C), $118.4(\mathrm{C}), 117.6(\mathrm{C}), 115.4(\mathrm{C})$. HRMS (ESI) $\mathrm{m} / \mathrm{z}$ : $[\mathrm{M}+\mathrm{Na}]^{+}$calcd. for $\mathrm{C}_{45} \mathrm{H}_{27} \mathrm{~N}_{5} \mathrm{Na}^{64} \mathrm{Zn}$ 724.14501, found 724.1454; $[\mathrm{M}+\mathrm{K}]^{+}$calcd. for $\mathrm{C}_{45} \mathrm{H}_{27} \mathrm{~N}_{5} \mathrm{~K}^{64} \mathrm{Zn} 740.11895$, found 740.1188 . UV-vis $\left(\mathrm{CH}_{2} \mathrm{Cl}_{2}\right): \lambda_{\max }(\log \varepsilon)$ 420 (5.73), 549 (4.31).

Synthesis of L3: Porphyrin L1 (82 mg, $0.11 \mathrm{mmol}$ ) was dissolved in 1,3-dichlorobenzene $(8 \mathrm{~mL})$ and the solution was heated to reflux. $\mathrm{Ru}_{3}(\mathrm{CO})_{12}$ was added stepwise by $10 \mathrm{mg}$ portion every 12 minutes. The required amount of $\mathrm{Ru}_{3}(\mathrm{CO})_{12}$ was $73 \mathrm{mg}(0.12 \mathrm{mmol})$ and no free-base was detected after 1.5 hours by TLC monitoring. The solvent was evaporated and the reaction crude was purified by filtration over alumina using $\mathrm{CH}_{2} \mathrm{Cl}_{2}$ and 9:1 $\mathrm{CH}_{2} \mathrm{Cl}_{2} / \mathrm{CH}_{3} \mathrm{CN}$ mixture as eluent. The product fraction was evaporated to dryness obtaining $\mathbf{L} 3$ as a dark violet solid (33mg, 34\%). ${ }^{1} \mathrm{H}$ NMR (400 MHz, acetone- $\left.d_{6}\right) \delta 8.60-8.51(\mathrm{~m}, 8 \mathrm{H}), 8.49$ $-8.00(\mathrm{~m}, 12 \mathrm{H}) \cdot{ }^{13} \mathrm{C}$ NMR was performed but no peaks significantly higher than the noise were detected. HRMS (ESI) $\mathrm{m} / \mathrm{z}$ : $[\mathrm{M}+\mathrm{Na}]^{+}$calcd. for $\mathrm{C}_{49} \mathrm{H}_{24} \mathrm{~N}_{8} \mathrm{ONa}^{102} \mathrm{Ru}$ 865.10087, found 865.1016; [M(H2O) $\left.+\mathrm{Na}\right]^{+}$calcd. for $\mathrm{C}_{49} \mathrm{H}_{26} \mathrm{~N}_{8} \mathrm{O}_{2} \mathrm{Na}^{102} \mathrm{Ru}$ 883.11144, found 883.1092. UV-vis $\left(\mathrm{CH}_{2} \mathrm{Cl}_{2}\right): \lambda_{\max }$ $(\log \varepsilon) 410$ (5.18), 534 (4.10), 610 (3.49).

Synthesis of L4: In air atmosphere, porphyrin 1 (50 mg, $7.1 \times 10^{-2} \mathrm{mmol}$ ) and $\mathrm{Cu}(\mathrm{AcO})_{2} \cdot 2 \mathrm{H}_{2} \mathrm{O}(43 \mathrm{mg}, 0.20 \mathrm{mmol}$ ) were dissolved in $10 \mathrm{~mL}$ of a $\mathrm{CHCl}_{3} / \mathrm{MeOH} 4: 1$ mixture. The mixture was refluxed for 5 hours, until the free-base porphyrin was no longer detected by TLC analysis, and evaporated to dryness. The reaction crude was filtered over a short pad of alumina using $\mathrm{CH}_{2} \mathrm{Cl}_{2}$ as eluent. The fraction containing the porphyrin complex was evaporated to dryness obtaining $\mathbf{L} 4$ as a red solid ( $30 \mathrm{mg}$, $55 \%) .{ }^{1} \mathrm{H}$ NMR (400 MHz, $\left.\mathrm{CDCl}_{3}\right) \delta 7.81$ (br). ${ }^{13} \mathrm{C}$ NMR was performed but no peaks significantly higher than the noise were detected. HRMS (ESI) $\mathrm{m} / \mathrm{z}$ : $[\mathrm{M}+\mathrm{Na}]^{+}$calcd. for $\mathrm{C}_{48} \mathrm{H}_{24} \mathrm{~N}_{8} \mathrm{Na}^{63} \mathrm{Cu} 798.13121$, found 798.1309; $[\mathrm{M}+\mathrm{K}]^{+}$calcd. for $\mathrm{C}_{48} \mathrm{H}_{24} \mathrm{~N}_{8} \mathrm{~K}^{63} \mathrm{Cu} 814.10515$, found 814.1044. Elemental Analysis calcd. for $\mathrm{C}_{48} \mathrm{H}_{24} \mathrm{~N}_{8} \mathrm{Cu} \cdot 4 / 3 \mathrm{H}_{2} \mathrm{O}$ : C, 72.04; $\mathrm{H}, 3.36 ; \mathrm{N}, 14.00$; found: C, 72.29; $\mathrm{H}, 3.56 ; \mathrm{N}, 13.76$. UV-vis $\left(\mathrm{CH}_{2} \mathrm{Cl}_{2}\right): \lambda_{\max }(\log \varepsilon) 415$ (5.70), 539 (4.34).

\section{General procedure for the binding constants measurements}

A stock solution $(\mathbf{A})$ of complex $\mathbf{L}\left(2.0 \times 10^{-5} \mathrm{M}\right.$ for zinc poprhyrins $\mathbf{L} 2$, $\mathbf{L}$, L6 and $6.0-1.0 \times 10^{-6} \mathrm{M}$ for L3) in dry dichloromethane was prepared and employed as solvent for the preparation of a second solution (B) containing the pyridine species $\mathbf{P}$. Different aliquots of solution $\mathbf{B}$ were withdrawn and diluted with solution $\mathbf{A}$ in order to reach a volume of $2 \mathrm{~mL}$. UV-Vis spectra of each sample were recorded using $3 \mathrm{~mL}$ quartz cuvettes with $10 \mathrm{~mm}$ 
path length. Binding constants were evaluated considering a 1:1 stoichiometry and using the software BindFit ${ }^{\mathrm{TM}}$ with Nelder-Mead method.

\section{General procedure for the catalytic experiments}

In a Schlenk tube the bromopyridine species (41 $\mathrm{mg}, 0.26 \mathrm{mmol})$, phenyl boronic acid (63 $\mathrm{mg}, 0.52 \mathrm{mmol})$, a porphyrin species $L\left(1.3 \times 10^{-2} \mathrm{mmol}\right)$ if required, dodecane $\left(20 \mu \mathrm{L}, 8.8 \times 10^{-2} \mathrm{mmol}\right)$ and $\mathrm{K}_{2} \mathrm{CO}_{3}(72 \mathrm{mg}, 0.52 \mathrm{mmol})$ were suspended in toluene $(1.0 \mathrm{~mL})$. After stirring for 5 minutes, $250 \mu \mathrm{L}$ of a $5.2 \times 10^{-3} \mathrm{M}$ solution of $\mathrm{Pd}(\mathrm{OAc})_{2}$ in toluene were added to the mixture and the Schlenk tube was placed in a pre-heated oil bath $\left(80^{\circ} \mathrm{C}\right)$. The catalytic reactions were followed by GC using dodecane as the internal standard. The competition experiment was performed by adding also bromobenzene $(27 \mu \mathrm{L}, 0.26 \mathrm{mmol})$ to the initial toluene suspension.

\section{Acknowledgements}

The research leading to these results has received funding from the People Programme (Marie Curie Actions) of the European Union's Seventh Framework Programme (FP7/2007-2013) under REA grant agreement n. PCOFUND-GA-2013-609102, through the PRESTIGE programme coordinated by Campus France. Financial support from CNRS, Université de Rennes 1, Rennes Métropole, and Région Bretagne (Stratégie d'Attractivité Durable and Boost'Europe) is acknowledged.

\section{Conflict of interest}

The authors declare no conflict of interest.

Keywords: supramolecular catalysis $•$ porphyrins $•$ palladium $•$ pyridines $\cdot$ cross-coupling

[1] a) R. Noyori, Nature Chem. 2009, 1, 5-6; b) K. Sanderson, Nature 2011 469, 18-20; c) R. A. Sheldon, Chem. Soc. Rev. 2012, 41, 1437-1451; d) G. Rothenberg, Catalysis: Concepts and Green Applications, Wiley-VCH, Weinheim, 2008; e) M. Beller, Chem. Soc. Rev. 2011, 40, 4891-4892.

[2] a) J. F. Hartwig, Organotransition Metal Chemistry: From Bonding to Catalysis, University Science Books, Sausalito, 2009; b) A. de Meijere, S. Braese, M. Oestreich, Metal-Catalyzed Cross-Coupling Reactions and More, Wiley- VCH, Weinheim, 2014.

[3] a) P. W. N. M. van Leeuwen, Homogeneous Catalysis: Understanding the Art, Kluwer, Dordrecht, 2004; b) P. C. J. Kamer, P. W. N. M. van Leeuwen, Phosphorus(III) Ligands in Homogeneous Catalysis: Design and Synthesis, Wiley-VCH, Weinheim, 2012.

[4] a) J. P. Stambuli, J. F. Hartwig, Curr. Opin. Chem. Biol. 2003, 7, 420426; b) G. Cennari, U. Piarulli, Chem. Rev. 2003, 103, 3071-3100; c) M. T. Reetz, Angew. Chem. Int. Ed. 2008, 47, 2556-2588; Angew. Chem. 2008, 120, 2592-2626; d) D. W. Robbins, J. F. Hartwig, Science, 2011, 333, 1423-1427.

[5] a) M. S. Sigman, K. C. Harper, E. N. Bess, A. Milo, Acc. Chem. Res. 2016, 49, 1292-1301; b) S. Raugei, D. L. DuBois, R. Rousseau, S. Chen, M.-H. Ho, R. M. Bullock, M. Dupuis, Acc. Chem. Res. 2015, 48, 248-255

[6] a) P. W. N. M. van Leeuwen, Supramolecular Catalysis, Wiley-VCH, Weinheim, 2008; b) M. Raynal, P. Ballester, A. Vidal-Ferran, P. W. N. M. van Leeuwen, Chem. Soc. Rev. 2014, 43, 1660-1733; c) S. Das, G. W. Brudvig, R. H. Crabtree, Chem. Commun. 2008, 413-424.
[7] a) C. J. Brown, F. D. Toste, R. G. Bergman, K. N. Raymond, Chem. Rev 2015, 115, 3012-3035; b) S. H. A. M. Leenders, R. Gramage-Doria, B. de Bruin, J. N. H. Reek, Chem. Soc. Rev. 2015, 44, 433-448.

[8] a) P. Dydio, J. N. H. Reek, Chem. Sci. 2014, 5, 2135-2145; b) H. J. Davis, R. J. Phipps, Chem. Sci. 2017, 8, 864-877; c) A. J. Neel, M. J. Hilton, M. S. Sigman, F. D. Toste, Nature 2017, 543, 637-646.

[9] a) B. Breit, W. Seiche, Pure Appl. Chem. 2006, 78, 249-256; b) J. Meeuwissen, J. N. H. Reek, Nature Chem. 2010, 2, 615-621.

[10] a) A. M. Lifschitz, M. S. Rosen, C. M. McGuirk, C. A. Mirkin, J. Am. Chem. Soc. 2015, 137, 7252-7261; b) V. Blanco, D. A. Leigh, V. Marcos, Chem Soc. Rev. 2015, 44, 5341-5370; c) M. Schmittel, Chem. Commun. 2015, 51, 14956-14968.

[11] E. Lindback, S. Dawaigher, K. Warnmark, Chem. Eur. J. 2014, 20, 13432-13481.

[12] a) A. J. Kirby, Angew. Chem. Int. Ed. 1996, 35, 707-724; Angew. Chem. 1996, 108, 770-790; b) A. J. Kirby, F. Hollender, From Enzyme Models to Model Enzymes, RSC Publishing, Cambridge, 2009; c) S. F. M. van Dongen, J. A. A. W. Elemans, A. E. Rowan, R. J. M. Nolte, Angew. Chem. Int. Ed. 2014, 53, 11420-11428; Angew. Chem. 2014, 126, 11604-11612.

[13] H. K. A. C. Coolen, J. A. M. Meeuwis, P. W. N. M. van Leeuwen, R. J. M. Nolte, J. Am. Chem. Soc. 1995, 117, 11906-11913.

[14] a) K. M. Kadish, K. M. Smith, R. Guillard, Handbook of Porphyrin Science, Vol. 1-44, World Scientific, Singapore, 2010-2016; b) I. Beletskaya, V. S. Tyurin, A. Y. Tsivadze, R. Guillard, C. Stern, Chem. Rev. 2009, 109, 1659-1713.

[15] a) S. Yamaguchi, T. Katoh, H. Shinokubo, A. Osuka, J. Am. Chem. Soc 2007, 129, 6392-6393; b) H. Yorimitsu, A. Osuka, Asian J. Org. Chem. 2013, 2, 356-373; c) M. Kadri, J. Hou, V. Dorcet, T. Roisnel, L. Bechki, A. Miloudi, C. Bruneau, R. Gramage-Doria, Chem. Eur. J. 2017, 23, 5033-5043.

[16] (a) D. Leow, G. Li, T.-S. Mei, J.-Q. Yu, Nature 2012, 486, 518-522; (b) L. Wan, N. Dastbaravardeh, G. Li, J.-Q. Yu, J. Am. Chem. Soc. 2013, 135, 18056-18059; (c) G. Yang, P. Lindovska, D. Zhu, J. Kim, P. Wang, R.-Y. Tang, M. Movassaghi, J.-Q. Yu, J. Am. Chem. Soc. 2014, 136, 1080710813; (d) Y.-F. Yang, G.-J. Cheng, P. Liu, D. Leow, T.-Y. Sun, P. Chen, X. Zhang, J.-Q. Yu, Y.-D. Wu, K. N. Houk, J. Am. Chem. Soc. 2014, 136, 344-355; (e) G.-J. Cheng, Y.-F, Yang, P. Liu, P. Chen, T.-Y. Sun, G. Li, X. Zhang, K. N. Houk, J.-Q. Yu, Y.-D. Wu, J. Am. Chem. Soc. 2014, 136, 894-897; (f) R.-Y. Tang, G. Li, J.-Q. Yu, Nature 2014, 507, 215-220; (g) M. Bera, A. Modak, T. Patra, A. Maji, D. Maiti, Org. Lett. 2014, 16, 57605763; (h) M. Bera, A. Maji, S. K. Sahoo, D. Maiti, Angew. Chem. Int. Ed. 2015, 54, 8515-8519; Angew. Chem. 2015, 127, 8635-8639; (i) Y. Deng, J.-Q. Yu, Angew. Chem. Int. Ed. 2015, 54, 888-891; Angew. Chem. 2015, 127, 902-905; (j) S. Bag, T. Patra, A. Modak, A. Deb, S. Maity, U. Dutta, A. Dey, R. Kancherla, A. Maji, A. Hazra, M. Bera, D. Maiti, J. Am. Chem. Soc. 2015, 137, 11888-11891; (k) T. Patra, S. Bag, R. Kancherla, A. Mondal, A. Dey, S. Pimparkar, S. Agasti, A. Modak, D. Maiti, Angew. Chem. Int. Ed. 2016, 55, 7751-7755; Angew. Chem. 2016, 128, 78827886; (I) M. Bera, S. K. Sahoo, D. Maiti, ACS Catal. 2016, 6, 3575-3579; (m) A. Modak, A. Mondal, R. Watile, S. Mukherjee, D. Maiti, Chem. Commun. 2016, 52, 13916-13919; (n) A. Maji, S. Guin, S. Feng, A. Dahiya, V. K. Singh, P. Liu, D. Maiti, Angew. Chem. Int. Ed. 2017, 56, 14903-14907; Angew. Chem. 2017, 129, 15099-15103; (o) L. Fang, T. G. Saint-Denis, B. L. H. Taylor, S. Ahlquist, K. Hong, S.-S. Liu, L.-L. Han, K. N. Houk, J.-Q. Yu, J. Am. Chem. Soc. 2017, 139, 10702-10714; (p) Z. Zhang, K. Tanaka, J.-Q. Yu, Nature 2017, 543, 538-542; (q) A. Modak, T. Patra, R. Chowdhury, S. Raul, D. Maiti, Organometallics 2017, 36, 2418-2423; (r) G. Yang, D. Zhu, P. Wang, R.-Y. Tang, J.-Q. Yu, Chem Eur. J. 2018, 24, 3434-3438.

[17] a) M. Marty, Z. Clyde-Watson, L. J. Twyman, M. Naksh, J. K. M. Sanders Chem. Commun. 1998, 2265-2266; b) M. Nakash, Z. Clyde-Watson, N Feeder, J. E. Davies, S. J. Teat, J. K. M. Sanders, J. Am. Chem. Soc. 2000, 122, 5286-5293.

[18] M. Saito, Y. Nishibayashi, S. Uemura, Organometallics 2004, 23, 40124017. 
[19] a) K. Hatano, K. Kawasaki, S. Munakata, Y. litaka, Bull. Chem. Soc. Jpn. 1987, 60, 1985-1992; b) A. C. Tome, A. M. S. Silva, I. Alkorta, J. Elguero, J. Porph. Phthal. 2011, 15, 1-28.

[20] CCDC 1843363 (for [L5•P5]), 1843364 (for L2) and 1843365 (for [L2·P5]) contain the supplementary crystallographic data for this paper. These data can be obtained free of charge from The Cambridge Crystallographic Data Centre.

[21] a) M. Morisue, T. Morita, Y. Kuroda, Org. Biomol. Chem. 2010, 8, 34573463; b) J. S. Summers, A. M. Stolzenberg, J. Am. Chem. Soc. 1993 115, 10559-10567; c) C. H. Kirksey, P. Hambright, C. B. Storm, Inorg Chem. 1969, 8, 2141-2144; d) R. J. Abraham, G. R. Bedford, B. Wright, Org. Magn. Reson. 1982, 18, 45-52; e) G. Szintay, A. Horvath, Inorg. Chim. Acta 2000, 310, 175-182.

[22] S. J. Webb, J. K. M. Sanders, Inorg. Chem. 2000, 39, 5912-5919.

[23] J. Cremers, S. Richert, D. V. Kondratuk, T. D. W. Claridge, C. R. Timmel, H. L. Anderson, Chem. Sci. 2016, 7, 6961-6968.

[24] R. Cacciapaglia, S. Di Stefano, L. Mandolini, Acc. Chem. Res. 2004, 37, 113-122.

[25] a) K. Inada, N. Miyaura, Tetrahedron 2000, 56, 8657-8660; b) M. Feuerstein, H. Doucet, M. Santelli, Tetrahedron Lett. 2001, 42, 5659$5662 ;$ c) I. Kiyoshi, N. Kazuharu, N. Yukio, K. Shinichi, Bull. Chem. Soc. Jpn. 1986, 59, 2141-2149.
[26] For examples see: a) G. K. Anderson, M. Lin, Inorg. Synth. 1990, 28, 60 63; b) M. M. Olmstead, P.-P. Wei, A. S. Ginwalla, A. L. Balch, Inorg. Chem. 2000, 39, 4555-4559.

[27] (a) C. Bianchini, A. Meli, W. Oberhauser, Organometallics 2003, 22, 4281-4285; (b) V. I. Bakhmutov, J. F. Berry, F. A. Cotton, S. Ibragimov, C. A. Murillo, Dalton Trans. 2005, 1989-1992

[28] (a) D. H. R. Barton, P. Langlois, T. Okano, N. Ozbalik, Tetrahedron Letters 1990, 31, 325-326; (b) E. V. Evdokimova, V. V. Lunin, P. V. Afanasiev, I. I. Moiseev, Mendeleev Commun. 1993, 31, 1-2; (c) S. A. Kurzeev, G. M. Kazankov, A. D. Ryabov, Inorg. Chimica Acta 2002, 340, 192-196; (d) E. H. P. Tan, G. C. Lloyd-Jones, J. N. Harvey, A. J. J. Lennox, B. M. Mills, Angew. Chem. Int. Ed. 2011, 50, 9602-9606; Angew. Chem. 2011, 123, 9776-9780; (e) N. L. S. Yue, M. C. Jennings, R. J. Puddephatt, Polyhedron 2016, 108, 67-73.

[29] a) N. Kudo, M. Perseghini, G. C. Fu, Angew. Chem. Int. Ed. 2006, 45, 1282-1284; Angew. Chem. 2006, 118, 1304-1306; b) K. Billingsley, S. L. Buchwald, J. Am. Chem. Soc. 2007, 129, 3358-3366; c) S. Ge, J. F. Hartwig, Angew. Chem. Int. Ed. 2012, 51, 12837-12841; Angew. Chem. 2012, 124, 13009-13013.

[30] K. Yamanishi, M. Miyazawa, T. Yairi, S. Sakai, N. Nishina, Y. Kobori, M. Kondo, F. Uchida, Angew. Chem. Int. Ed. 2011, 50, 6583-6586; Angew. Chem. 2011, 123, 6713-6716.

[31] L. Leondiadis, M. Momenteau, J. Org. Chem. 1989, 54, 6135-6138. 


\section{Entry for the Table of Contents}

\section{FULL PAPER}

Ground control: Supramolecular catalysts made up from porphyrin scaffolds with peripheral palladium ions (see picture) modulate the reactivity of structurally similar substrates by tuning the properties of the binding site $(\mathbf{A})$, which stands eight chemical bonds apart from the active sites (Pd).

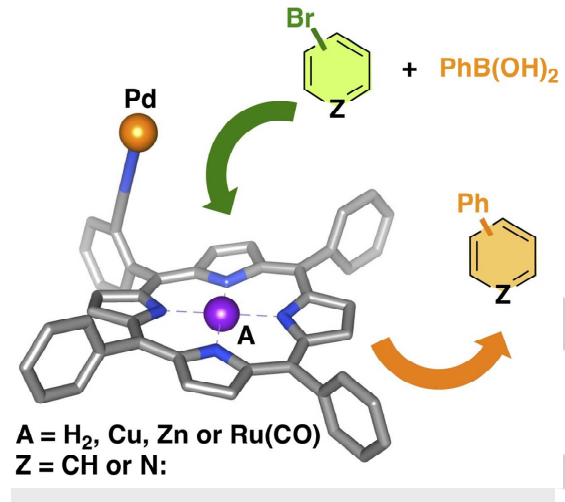

| Supramolecular Catalysis

Paolo Zardi, Thierry Roisnel, Rafael Gramage-Doria*

Page No. - Page No.

A Supramolecular Palladium Catalyst Displaying Substrate Selectivity by Remote Control 